\title{
THE DEVELOPMENT OF SCIENCES IN AL-QUR'AN PERSPECTIVES
}

\author{
Soleha \& Adrian \\ STAIN Syaikh Abdurrahman Siddik, Bangka Belitung \\ e-mail: adrian.rusman.gumay@gmail.com
}

\begin{abstract}
This research applied the method of interpretation and bi 'l-ra'y approach. It tried to reinvent the spirit of the Qur'an and Hadith to push humankind to develop science integratively and to make it beneficial for human beings and nature. The research confirmed that human beings as khalifah fi ' l-ard, was given the right and freedom to explore what is on this earth and its contents with all its potential. Even in the Qur'an, Allah has made available all materials for the development of science, al ayah alkawniyyah verses. Al-Qur'an as a resource of knowledge in Islam stated that one of the advantages human beings from the others is that they were endowed reason to search and explore science for the progress of human beings.

Penelitian ini dengan menggunakan metode interpretasi dan pendekatan $b i$ ' l-ra'y, mencoba untuk menciptakan kembali semangat Qur'an dan Hadits untuk mendorong manusia untuk mengembangkan ilmu pengetahuan secara integratif dan membantu untuk manusia dan alam. Penelitian ini menegaskan bahwa manusia sebagai khaliffah fi 'l-ard, diberi hak dan kebebasan untuk dieksplorasi apa yang ada di bumi ini dan isinya dengan semua potensinya. Bahkan dalam al-Qur'an Allah telah menyediakan bahan-bahan untuk pengembangan ilmu pengetahuan, yang tentunya di sisi lain dengan ayat kawniyyah. Al-Qur'an sebagai sumber pengetahuan dalam Islam yang menyatakan bahwa salah satu keuntungan manusia dibandingkan makhluk yang lain adalah diberikan pikiran untuk mencari dan mengeksplorasi ilmu pengetahuan untuk kemajuan manusia.
\end{abstract}

Keywords: Islamic science, al-Qur'an, integration, mașlaḥat, khaliffah fi 'l-ard 


\section{A. Pendahuluan}

Islam sangat memperhatikan akan pentingnya ilmu pengetahuan, teknologi dan seni dalam kehidupan manusia. Martabat manusia disamping ditentukan oleh tingkat ketaqwaannya kepada Allah SWT, juga ditentukan oleh kemampuan manusia dalam mengembangkan ilmu pengetahuan yang dimilikinya. Allah memberikan sedikit ilmu-Nya kepada manusia untuk melebihkan dari ciptaan-Nya yang lain. Oleh sebab itu, menjadi kewajiban bagi manusia untuk menuntut ilmu.

Ilmu pengetahuan atau sains, secara singkat dapat dirumuskan sebagai himpunan pengetahuan manusia yang dikumpulkan melalui proses pengkajian dan dapat diterima oleh rasio, yang artinya menurut Baiquni dapat dinalar. ${ }^{1}$ Sehingga dapat dikatakan bahwa sains adalah himpunan rasionalitas kolektif manusia. Dalam konteks sains dan teknologi, al-Qur'an dan al-Sunnah memberikan ketegasan-ketegasan bahwa belajar adalah kewajiban individual yang harus disertai dengan keterbukaan untuk bisa mempelajari ilmu dan teknologi apa saja yang baik untuk umat manusia, dan dari tokoh serta latar belakang keagamaan yang mungkin berbeda. Dengan penguasaan sains dan teknologi tersebut, diharapkan umat Islam menjadi masyarakat yang kompetitif dan unggul. Ilmu-ilmu yang dikembangkan atas dasar keimanan dan ketaqwaan kepada Allah SWT, akan memberikan jaminan kemaslahatan umat manusia.

Dalam perjalanan sejarah, kehidupan agama Islam dalam panggung sejarah peradaban manusia memiliki arti sendiri, termasuk dalam bidang ilmu pengetahuan. Islam memberi warna khas corak peradaban yang diwariskan Romawi-Yunani yang pernah berjaya selama satu mellenium sebelumnya. Walaupun pada awalnya karakteristik ini tidak mudah bekerja, karena pengaruh peradaban Hellenisme ${ }^{2}$ yang begitu kuat, namun dalam waktu yang

\footnotetext{
${ }^{1}$ A. Baiquni, Islam dan Ilmu Pengetahuan, (Jakarta: Pustaka ITB, 1983), h. 1.

${ }^{2}$ Istilah "Hellenisme" pertama kali diperkenalkan oleh ahli sejarah dari Jerman, J.G. Droysen. Ia menggunakan perkataan "Hellenismus" sebagai sebutan untuk masa yang dianggapnya sebagai periode peralihan antara Yunani Kuno dan dunia Kristen. Droysen lupa peranan Roma dalam agama Kristen (dan membatasi seolah-olah hanya Yunani saja yang berperan). Namun ia diakui telah berhasil mengidentifikasi suatu kenyataan sejarah yang amat penting. Biasanya yang disebut zaman Hellenik yang merupakan peralihan itu ialah masa sejak tahun 323 sampai 30 SM. atau dari saat kematian Iskandar Agung sampai penggabungan Mesir kedalam kekaisaran Romawi. Sebab dalam periode itu muncul banyak kerajaan di sekitar Laut Tengah, khususnya pesisir Timur dan Selatan seperti Syiria dan Mesir, yang diperintah oleh bangsa Macedonia dari Yunani. Akibatnya, mereka ini membawa berbagai per-
} 
tidak begitu panjang akhirnya kaum Muslimin dapat memainkan peran peradabannya yang unik selama beberapa abad. ${ }^{3}$

Oleh karena itu, Islam menghendaki umatnya untuk memiliki ilmu pengetahuan, baik ilmu pengetahuan agama maupun ilmu pengetahuan umum. Karena Islam itu sendiri, tidak memandang adanya dikotomi. Dalam pandangan Islam, ilmu itu suci. Ulama ataupun intelektual memiliki kesamaan posisi, sekalipun memiliki corak dan pemahaman yang berbeda dalam pengembangannya. Karena ilmu pengetahuan bertujuan untuk mengkonseptualisasikan fenomena-fenomena yang terjadi di dalam kehidupan.

\section{B. Ilmu Pengetahuan dalam Perspektif Islam}

Ilmu pengetahuan merupakan salah satu isi pokok kandungan kitab suci alQur'an. Sehingga kata 'ilmu itu sendiri disebutkan dalam al-Qur'an sebanya105 kali, tetapi dengan kata jadinya ia disebut lebih dari 744 kali. ${ }^{4}$ Sedangkan Imam Syafi'e menyebutkan kata 'ilmu dengan berbagai bentuknya terulang sebanyak 854 kali dalam al-Qur'an, dan digunakan dalam arti proses pencapaian pengetahuan dan objek pengetahuan. Ilmu dari segi bahasa berati kejelasan, karena itu segala yang terbentuk dari akar katanya mempunyai ciri kejelasan. Jadi dalam batasan ini faktor kejelasan merupakan bagian penting dari ilmu. Sedangkan dari segi maknanya, pengertian ilmu sepanjang terbaca dalam pustaka menunjukkan sekurang-kurangnya pada tiga hal, yakni pengetahuan, aktivitas dan metode. ${ }^{5}$ Jadi, secara umum ilmu adalah kumpulan pengetahuan yang tersusun secara sistematis, koheren dan komprehensif dan rasional.

Banyaknya kata Imu yang digunakan, ini berarti menandakan bahwa ajaran Islam sebagaimana tercermin dalam al-Qur'an sangat kental dengan nuansa yang berkaitan dengan ilmu, sehingga dapat menjadi ciri penting dari Islam. Hal ini diungkapkan oleh Mujamil bahwa ilmu mengemban nilai-nilai

ubahan besar dalam banyak bidang di kawasan itu, antara lain bahasa (daerah-daerah itu didominasi bahasa Yunani) dan pemikiran (ilmu pengetahuan Yunani, terutama filsafatnya, diserap oleh daerahdaerah itu melalui berbagai cara. Nurcholis Madjid, Islam Doktrin dan Peradaban, Sebuah Telaah Kritis tentang Masalah Keimanan, Kemanusiaan dan Kemoderenan, cet. IV, (Jakarta: Paramadina, 2000), h. 233.

3Tim Penyusun, Pengembangan Kepribadian Pendidikan Agama Islam pada Perguruan Tinggi, (Jakarta: Direktorat Jenderal Pendidikan Islam Direktorat Pendidikan Tinggi Islam, 2009), h. 88.

${ }^{4}$ M. Dawam Rahardjo, Ensiklopedi al-Qur'an: Tafsir Sosial Berdasarkan Konsep-konsep Kunci, (Jakarta: Paramadina, 2002), h. 531.

5Imam Syafi'e, Konsep Ilmu Pengetahuan dalam al-Qur'an, (Yogyakarta: UII Press, 2000), h. 26- 27. 
ketuhanan, sebagai nilai yang memberikan kesejahteraan dan kedamaian bagi semua makhluk. ${ }^{6}$ Sejalan dengan ungkapan tersebut Baedhowi menyebutkan bahwa al-Qur'an sebagai sumber primer ajaran Islam mengandung bahasabahasa simbolis yang kaya akan analisis-analisis tematik dan konseptual.7 ${ }^{7}$ Oleh karena itu, Islam sangat gigih dalam mendorong umat manusia dalam menuntut ilmu ${ }^{8}$ serta mendudukkannya ke dalam posisi yang mulia. Hal ini telah termaktub dalam al-Qur'an yang merupakan Kalāmullāh yang diturunkan melalui Malaikat Jibril kepada Nabi Muhammad SAW, sebagaimana dijelaskan dalam al-Qur'an:

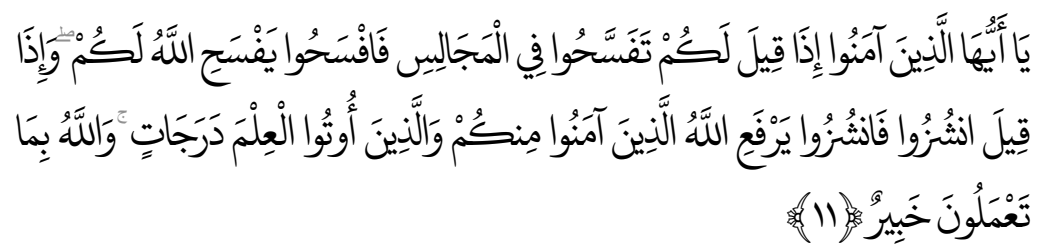

"Hai orang-orang beriman apabila dikatakan kepadamu: "Berlapang-lapanglah dalam majelis", maka lapangkanlah niscaya Allah akan memberi kelapangan untukmu. Dan apabila dikatakan: "Berdirilah kamu", maka berdirilah, niscaya Allah akan meninggikan orang-orang yang beriman di antaramu dan orang-orang yang diberi ilmu pengetahuan beberapa derajat. dan Allah Maha Mengetahui apa yang kamu kerjakan."9

Dalam sebuah Hadits Nabi disebutkan:

$$
\text { من سلك طريقا يلتمس فيه علما ، سهل الله له به طريقا إلى الجنة ... }
$$

"Barang siapa menempuh jalan untuk mencari ilmu, maka Allah memudahkan jalan baginya untuk menuju surga."10

\footnotetext{
6Mujamil Qomar, Epistemologi Pendidikan Islam dari Metode Rasional Hingga Metode Kritik, (Jakarta: Erlangga, 2007), h. 155.

7Baedhowii, Antropologi al-Qur'an, (Yogyakarta: LKIS, 2009), h. 183.

${ }^{8}$ Dalam Kamus Besar Bahasa Indonesia, ilmu merupakan kata yang berasal dari bahasa Arab 'alimaya'lamu yan berarti tahu atau mengetahui. Dalam bahasa Inggris biasanya ilmu dipadankan dengan kata science, sedang pengetahuan dengan knowledge Dalam bahasa Indonesia kata science umumnya diartikan dengan ilmu tapi sering juga diartikan dengan ilmu pengetahuan. Pengertian ilmu diantaranya adalah pengetahuan tentang sesuatu bidang yang disusun secara bersistematis menurut metodemetode tertentu yang dapat digunakan untuk menerangkan gejala-gejala tertentu di bidang (pengetahuan) itu. Science is knowledge arranged in a system especially obtained by observation and testing offact. Baca: English Reader's dictionary.

${ }^{9}$ QS. al-Mujadilah [58]: 11.

${ }^{10}$ al-Turmudzi, al-Jāmi' al-Șahịh Sunan al-Tirmidhi, Juz. V, h. 38. Lihat juga Abu Daud Sulaiman, Sunan Abū Dawūd, juz. II, (Bairut:Dār Ihyā' al-Turāth al-'Araby, t.th.), h. 354.
} 
Pandangan al-Qur'an tentang ilmu dan teknologi dapat diketahui prinsipprinsipnya dari analisis wahyu pertama yang diterima oleh Nabi Muhammad. Hasan Basri menyebutkan Surat al-Alaq 1-5 merupakan dasar sains dan teknologi dalam Islam. Allah memerintahkan kita membaca, meneliti, mengkaji dan membahas dengan kemampuan intelektual. Surat ini merangsang daya kreativitas kita untuk berinovasi, mengembangkan keimanan dengan rasio dan logika yang dimiliki manusia. Kewajiban membaca dan menulis (memperdalam sains dengan meneliti) menjadi interen Islam dan penguasaan, dan keberhasilan suatu penelitian atas restu Allah. ${ }^{11}$

Secara normatif, Allah SWT telah memerintahkan hamba-Nya untuk senantiasa membaca, meneliti, menganalisa, mendalami bahkan mengeksplorasi apa saja dengan pendekatan yang termaktub dalam al-Qur'an. Sehingga makna iqra' mengandung segala sesuatu yang dapat dijangkau dengan pancaindra manusia. Dari QS. al-Alaq [96]: 1 dapat diambil dua pengertian yaitu, pertama, Islam menganggap penting belajar dan meneliti, kedua, secara normatif Islam tidak mengakui adanya dikotomi dalam pengembangan ilmu pengetahuan.

Selain itu, Allah telah mengisyaratkan di dalam al-Qur'an tentang keutamaan dalam pengembangan ilmu pengetahuan/sains untuk kemajuan dan peradaban manusia. Hampir 14 abad yang silam, ayat al-Qur'an telah mengisyaratkan secara ilmiah kepada bangsa jin dan manusia untuk menjelajahi angkasa luar, asalkan mereka memiliki kemampuan dan kekuatan (sulțān):

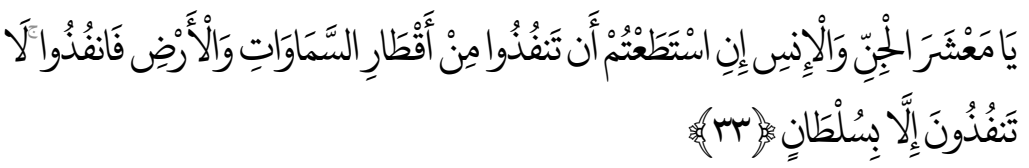

“Hai jama'ah jin dan manusia, jika kamu sanggup menembus (melintasi) penjuru langit dan bumi, maka lintasilah, kamu tidak dapat menembusnya kecuali dengan kekuata." 12

Para ulama menafsirkan, kekuasanan di sini adalah ilmu pengetahuan atau sains dan teknologi. Ini telah dibuktikan di era modern sekarang, dengan ditemukannya alat transformasi yang mampu menembus luar angkasa. Bangsa-

\footnotetext{
${ }^{11}$ Hasan Basri Jumin, Sains dan Teknologi dalam Islam Tinjauan Genetis dan Ekologis, (Jakarta: Rajagrafindo Persada, 2012), h. 11-12.

${ }^{12}$ QS. al-Rahman [55]: 33.
} 
bangsa yang telah mencapai kemajuan dalam bidang sains dan teknologi telah berulang kali melakukan pendaratan di Bulan, Planet Mars, Jupiter dan planetplanet lainnya.

Kemajuan yang telah dicapai oleh bangsa-bangsa yang maju (bangsa Barat) dalam bidang ilmu pengetahuan, sains dan teknologi di abad modern ini, sebenarnya merupakan kelanjutan dari tradisi ilmiah yang telah dikembangkan oleh ilmuwan-ilmuwan Muslim pada abad pertengahan. Atau meminjam istilah Badri Yatim, ilmuwan Muslim telah banyak memberikan sumbangan kepada ilmuwan Barat, yaitu "kemajuan Barat pada mulanya bersumber pada peradaban Islam yang masuk ke Eropa melalui Spanyol",13 dan hal ini juga banyak diakui oleh sebagian dari mereka (ilmuwan Barat). ${ }^{14}$ Sains dan teknologi yang telah ditemukan oleh ilmuwan Muslim maupun Barat, baik dulu, sekarang dan yang akan datang. Hal ini telah membuktikan bahwa semua kebenaran informasi yang terkandung dalam al-Qur'an membuktikan kemukjizatan al-Qur'an sebagai sumber ilmu pengetahuan yang selalu terbuka untuk dikaji, diuji dan diteliti secara ilmiah oleh siapa pun.

\footnotetext{
13Baca: Badri Yatim, Sejarah Peradaban Islam, (Jakarta: Raja Grafindo Persada, 1997), h. 2.

${ }^{14} \mathrm{Hal}$ ini diakui oleh Briffault sebagai berikut: sebab sekalipun tidak ada satu segi pun yang tidak dimasuki pengaruh kebudayaan Islam yang penting tidak ada yang penting tidak ada yang begitu jelas yang hebat seperti dalam lahirnya kekuatan yang telah membentuk tenaga dunia modern yang permanen dan sumber tertinggi kemenangan Eropa itu ialah ilmu pengetahuan alam dan semangat ilmiahnya. Kemudian lebih tegas lagi ia menulis: Hutang ilmu pengetahuan kita kepada ilmu pengetahuan Arab bukan tergantung kepada penemuan-penemuan teori yang revolusioner; ilmu pengetahuan berhutang sekali kepada kebudayaan Islam. Dunia purba, seperti yang dapat kita lihat adalah dunia pra-ilmu. Astronomi dan matematika Yunani adalah suatu impor asing yang tidak seluruhnya dapat disesuaikan dalam kebudayaan Yunani. Orang Yunani telah membuat sistem, menyeragamkan dan membuat teori, tetapi cara yang memerlukan kesabaran tentang penyelidikan, pengumpulan tentang pengetahuan positif serta metode-metode ilmu yanng begitu cermat, observasi yang begitu terperinci dan panjang serta pennyelidikan eksperimental, semua itu asing bagi perangai bangsa Yunani. Hanya di Alexanderia yang sudah menerima Helenisme terdapat juga perkenalan dengan pekerjaan ilmu itu yang sudah terbawa semasa dunia klasik purba. Apa yang kita namakan ilmu yang berkembang di Eropa sebagai hasil jiwa baru dalam mengadakan pembahasan metode-metode baru tentang penyelidikan, tentang eksperimen, obsevasi, pengukuran, tentang perkembangan ilmu pasti, tidak dikenal oleh bangsa Yunani. Jiwa dan metode-metode itu diperkenalkan kepada dunia Eropa oleh bangsa Arab. Mohammad Iqbal, Membangun Kembali Pikiran Agama dalam Islam, terj. Ali Audah etal., (Jakarta: Tinta Emas, 1966), h. 129. Sedangkan pengakuan Briffault dalam: Robert Briffault, The Making of Humanity, (Montana: Kessinger Publishing, LLC, 2010.), h.190.

Hal ini diakui pula oleh Nicholson dalam bukunya Literature History of Arab bahwa di zaman ini, kaum muslimin menjelajah tiga benua, untuk menuntut ilmu pengetahuan. Kembali mereka ke tanah air, ibarat lebah pulang ke sarang membawa sari madu. Kemudian mereka mengarang sejumlah besar kitab. Kitab-kitab mana merupakan dairatul màarif (encyclopedia) yang sangat berjasa yang telah mengantarkan kepada kita ilmu-ilmu baru yang belum pernah ada. A. Hasymi, Sejarah Kebudayaan Islam, (Jakarta: Bulan Bintang, 1979), h. 294.
} 


\section{Sumber Ilmu Pengetahuan}

Ilmu pengetahuan sebagai salah satu syarat manusia untuk mencapai kemajuan dan kesuksesan dalam hidupnya yang harus diraih melalui proses belajar. Karena jika ilmu pengetahuan yang didapat tanpa melaui proses belajar (diuji, dikaji dan diteliti secara ilmiah) dan merujuk kepada sumber yang benar maka akan menghasilkan ilmu yang "kurang bermanfaat".

Manusia sebagai makhluk Allah yang paling mulia dibandingkan dengan makhluk yang lain adalah terletak pada posisi akalnya, sehingga bisa membedakan antara kebaikan dan kejahatan. Ketika manusia bisa menggunakan akalnya dengan baik, maka manusia bisa melaksanakan tanggung jawabnya sebagai khalifah di muka bumi. Selain itu manusia dibekali oleh Allah dengan kemampuan untuk belajar dan mengetahui segala ciptaan-Nya, sebagaimana firman Allah:

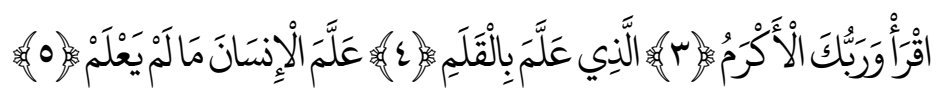

"Bacalah, dan Tuhanmulah yang Maha Pemurah, yang mengajar (manusia) dengan perantaran kalam, Dia mengajar kepada manusia apa yang tidak diketahuinya." 15

Maksud dari ayat di atas adalah Allah telah mengajarkan manusia dengan perantara baca dan tulis. Selain itu juga Allah telah menganugerahkan manusia dengan berbagai sarana untuk belajar seperti: penglihatan, pendengaran dan hati16 baik melalui ayat qawliyyah maupun ayat kawniyyah. Semua apa yang telah didapat dari pengetahuan yang dimilikinya semuanya itu akan akan dipertanggung jawabkan semua itu, sebagaimana firman Allah:

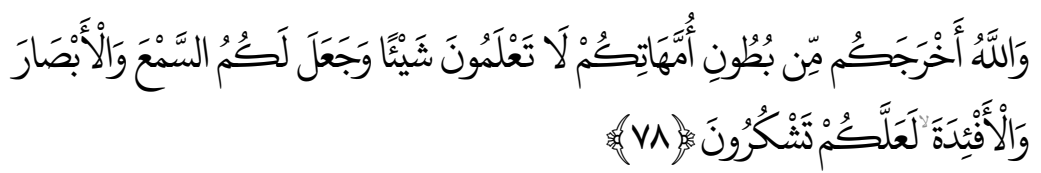

\footnotetext{
${ }^{15}$ QS. al-Alaq [96]: 3-5.

16al-Maududi mengatakan bahwa pendengaran merupakan pemeliharaan pengetahuan yang diperoleh dari orang lain. Pemeliharaan merupakan pengembangan pengetahuan dengan hasil observasi dan penelitian yang saling berkaitan. Hati merupakan sarana membersihkan ilmu pengetahuan dari kotoran dan noda sehingga lahirlah ilmu pengetahuan yang murni. Jika ketiga pengetahuan itu dipadukan, terciptalah ilmu pengetahuan yang sesuai dengan apa yang dikaruniakan Allah kepada manusia yang hanya dengan pengetahuan itulah manusia mampu mengatasi dan menundukkan makhluk lain agar tunduk pada hakikatnya. Lebih jelas baca". Aburrahman al-Nahlawi: Ușūl al-Tarbiyah al-Islāmiyyah wa Asālibuhāfi ' '-Bayti wa al-Madrasati wa al-Mujtamā', cet. II, (Beirut-Libanon: Dar al-Fikr al-Mu’ashir, 1983).
} 
"Dan Allah mengeluarkan kamu dari perut ibumu dalam keadaan tidak mengetahui sesuatupun, dan Dia memberimu pendengaran, penglihatan dan hati, agar kamu bersyukur." 17

Ilmu pengetahuan yang telah dicapai oleh manusia dengan segala potensi yang dimilikinya, semua itu akan ada pertanggungjawabannya di depan Allah.

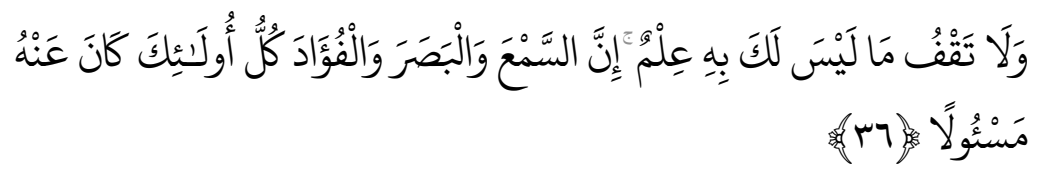

"Dan janganlah kamu mengikuti apa yang kamu tidak mempunyai pengetahuan tentangnya. Sesungguhnya pendengaran, penglihatan dan hati, semuanya itu akan diminta pertanggungan jawabnya." 18

Abu al-'Ainain menjelaskan, untuk mempermudah kajian dalam penyebutan alam semesta yang dalam kajian filsafat menggunakan istilah al-kawn, yang berarti segala sesuatu yang diciptakan Allah yang mencakup nama segala jenis makhluk, baik yang dapat dihitung maupun yang hanya dapat didiskripsikan saja. Al-kaun sebagai wujud makhluk Allah dapat dibagi dalam dua kategori yaitu 'àlam al-shahādah yang dikenal melalui pancaindra, seperti langit dan bumi, dan 'ālam al-ghayb yang hanya dapat dikenali melalui wahyu ilahi, seperti alam malaikat dan jin. ${ }^{19}$ Sejalan dengan pemikiran di atas, Sirajuddin menawarkan bahwa al-Qur'an, untuk merujuk alam dalam pengertian alam semesta (universe) itu, menggunakan kata al-samāwāt wa al-ard wa baynahumā, yang disebutkan al-Qur'an sebanyak 20 kali. Kata ini mengacu kepad dua alam yaitu, alam fisik seperti manusia, tumbuhan dan hewan dan alam non fisik atau alam gaib, seperti malaikat, alam jin, dan alam ruh. ${ }^{20}$

Oleh sebab itu, dengan segala sarana yang diberikan Allah kepada manusia melalui pendengaran, penglihatan, hati dan akal, manusia mengolah alam ${ }^{21}$ ini untuk dijadikan suatu yang bermanfaat bagi kehidupan.

\footnotetext{
${ }^{17}$ QS. al-Nahl [16]: 78.

${ }^{18}$ QS. al-Isra' [17]: 36.

${ }^{19}$ Ali Khallil Abu al-'Ainain, Fïlsafat al-Tabiyyah al-Islāmiyyah fi al-Qur'ān al-Karīm, cet. I, (t.t.p., Dār alFikr al-'Araby, 1980), h. 132.

${ }^{20}$ Sirajuddin Zar, Konsep Penciptaan Alam dalam Pemikiran Islam, Sains, dan al-Qur'an, cet. I, (Jakarta: Raja Grafindo Persada, 1994), h. 21.

21Menurut al-Jurjani, dalam Kitāb al-Ta'rîfāt, term "alam" secara bahasa berarti segala hal yang menjadi tanda bagi suatu perkara sehingga dapat dikenali, sedangkan secara terminologi berarti segala sesuatu yang maujud (maujudaat) selain Allah, yang dengan ini Allah dapat dikenali, baik dari segi nama
} 
Sejalan dengan penjelasan di atas, dalam pemikiran Islam ada dua sumber ilmu yaitu akal dan wahyu. Keduanya tidak boleh dipertentangkan. Manusia diberi kebebasan dalam mengembangkan akal budinya berdasarkan tuntutan al-Qur'an dan Sunnah Rasul. Atas dasar itu ilmu dalam pemikiran Islam ada yang bersifat abadi (perennial knowledge) tingkat kebenarannya bersifat mutlak (absolute), karena bersumber dari wahyu Allah, dan ilmu yang bersifat perolehan (acquired knowledge) dimana tingkat kebenarannya nisbi (relatif) karena bersumber dari akal pikiran manusia.

Selanjutnya akal sebagai pertimbangan antara intelek (budi) dan intuisi (hati) manusia, yaitu antara pikiran dan emosi manusia. Oleh karena itu, intelek berfungsi sebagai alat untuk memperoleh pengetahuan untuk alam nyata. Dalam membentuk pengetahuan, intelek terikat oleh yang konkret. Sedangkan intuisi adalah alat untuk alam tidak nyata. Dalam membentuk pengetahuan ia dapat melalukan lompatan dari tidak tahu tiba-tiba menjadi tahu. ${ }^{22}$

Mengutip penyataan Fazlur Rahman, bahwa alam semesta terjalin erat dan bekerja dengan regularitasnya, sehingga pantas kalau ia dikatakan sebagimana keajaiban Allah. ${ }^{23}$ Di dalam al-Qur'an disebutkan:

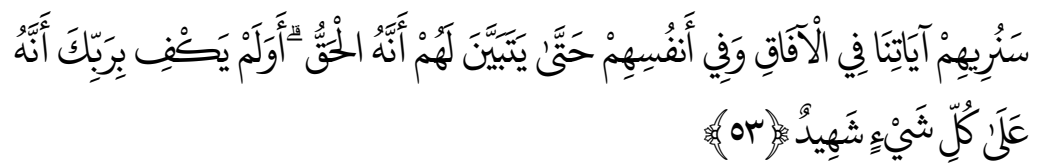

maupun sifatnya. Ali bin Muhammad al-Jarnuji, Kitāb al-Ta'rīfāt, cet. III, (Beirut: Dar Al-Kutub AlImiyyah, 1988), h. 145. Segala sesuatu selain Allah, itulah alam secara sederhana. Pengertian ini merupakan pengertian teologis, dalam arti berdasarkan yang dikemukakan oleh para teolog Islam.

Sedangkan menurut Jamil Shaliba, secara filosofis, "alam” adalah kumpulan jauhar (substansi) yang tersusun dari materi (maddah) dan bentuk (șūrah) yang ada di langit dan bumi. Jamil Shaliba, al-Mu'jam al-Falsafi, jilid III, (Beirut: Dar al-Kitab al-Lubnani, 1973), h. 45.

Sedangkan dalam Kamus Inggris-Indonesia, segala sesuatu yang ada di langit dan bumi, itulah alam berdasarkan rumusan filsafat. Alam dalam pengertian ini merupakan alam semesta atau jagat raya, yang dalam bahasa Inggris disebut universe. Jhon M. Echols dan Hasan Shadily, Kamus Inggris-Indonesia, cet. XXIII, (Jakarta: Gramedia, 1996), h. 618.

${ }^{22}$ Sebagai contoh dari pengetahuan manusia melalui intelek yaitu: seseorang yang akan mengetahui dan memahami alam semesta melalui astronomi. Ia tidak dapat melakukannya kecuali secara bertahap. Ia harus membekali pengetahuannya terlebih dahulu dengan mempelajari matematika, fisika dan kimia. Maka untuk mengetahui ketiganya ia harus memulainya dengan belajar mengenal huruf dan angka. Lain halnya dengan seseorang yang memperoleh pengetahuan melalui intuisi dengan melihat tentang keindahan sekuntum bunga. Cukup dengan melihat sekilas maka ia dapat mengambil kesimpulan tentang keindahan bunga tersebut. Ia tidak perlu mengukur diameter, jumlah kelopak atau menentukan berapa jenis-jenis warna yang ada pada bunga tersebut. 101.

${ }^{23}$ Fazlur Rahman, Tema Pokok al-Qur'an, terj. Anas Mahyuddin, cet. II, (Bandung: Pustaka, 1996), h. 
"Kami akan memperlihatkan kepada mereka tanda-tanda (kekuasaan) Kami di segala wilayah bumi dan pada diri mereka sendiri, hingga jelas bagi mereka bahwa al-Qur'an itu adalah benar. Tiadakkah cukup bahwa sesungguhnya Tuhanmu menjadi saksi atas segala sesuatu?" 24

Ayat ini mengungkapkan dengan jelas bahwa alam semesta merupakan tanda-tanda Tuhan. Alam sebagai sebuah tanda tentunya akan memberi petunjuk kepada yang ditandai, yaitu Tuhan. Dari sini banyak filosof mengatakan bahwa alam merupakan pantulan atau cermin sifat-sifat Tuhan. Meminjam istilah Toto Suharto alam semesta merupakan cermin universal yang dengannya Tuhan dapat dikenali. ${ }^{25}$

Di dalam al-Qur'an, ditemukan 750 lebih ayat yang menunjuk kepada fenomena alam semesta. Manusia dalam hal ini diminta untuk dapat memikirkannya agar dapat mengenal Tuhan melalui tanda-tanda-Nya. Mehdi Golshani dalam The Holy Quran and the Science of Nature, membagi ayat-ayat al-Qur'an yang berbicara tentang alam semesta ini dalam delapan kategori, ${ }^{26}$ yaitu: (1) Ayat-ayat al-Qur'an yang menggambarkan elemen-elemen pokok alam semesta dan menyuruh manusia untuk menyingkapnya. (2) Ayat-ayat alQur'an yang mencakukp masalah cara penciptaan alam semesta dan menyuruh manusia untuk menyingkap asal usulnya. (3) Ayat-ayat al-Qur'an yang menyuruh manusia untuk menyingkap bagaimana alam semesta ini terwujud. (4) Ayat-ayat al-Qur'an yang menyuruh manusia mempelajari fenomena alam. (5) Ayat-ayat al-Qur'an yang menunjukkan bahwa Allah bersumpah atas berbagai macam objek alam. (6) Ayat-ayat al-Qur'an yang merujuk kepada kemungkinan terjadinya beberapa fenomena alam. (7) Ayat-ayat al-Qur'an yang menekankan kelangsungan dan keteraturan penciptaan alam semesta oleh Allah. (8) Ayat-ayat al-Qur'an yang menjelaskan keharmonisan keberadaan manusia dengan alam semesta, dan ketundukan apa yang ada di langit dan di bumi kepada manusia.

Di dalam delapan kategori ayat-ayat al-Qur'an tersebut, Allah yang Mahakuasa menganjurkan kepada hamba-hamba-Nya untuk melihat dan memikirkan fenomena alam semesta. Dengan melihat dan memikirkannya, akan tampak

\footnotetext{
${ }^{24}$ QS. al-Fushshilat [41]:53.

25Toto Suharto, Filsafat Pendidikan Islam, cet. I, (Yogyakarta: Ar-Ruzz, 2006), h. 101.

${ }^{26}$ Mehdi Golshani, Filsafat Sains menurut al-Qur'an, terj. Agus Effendi, cet. X, (Bandung: Mizan, 1998), h. 62-65.
} 
keteraturan dan koordinasi sistem penciptaan alam ini yang merupakan keajaiban-keajaiban Allah bagi hamba-hamba-Nya. Dari segi ini, kedudukan alam semesta menurut Mehdi Golshani merupakan motifasi para ilmuwan Muslim untuk mempelajarinya, karena mereka beranggapan bahwa mengkaji alam semesta dan fenomenanya merupakan salah satu cara terbaik untuk mendekan diri kepada Allah. Mereka yakin bahwa mempelajari tanda-tanda allah di alam semesta dapat membuat mereka mampu menyingkap kesalinghubungan seluruh bagian alam semesta dan kesatuan yang tersembunyi di balik dunia yang penuh keragaman ini. ${ }^{27}$

Al-Qur'an tidak secara khusus mengungkapkan alam semesta dengan terma ālam dalam bentuk tunggal, tapi menyebutnya dalam bentuk jamak, yaitu 'ālamīn yang diungkapkan sebanyak 73 kali dalam al-Qur'an. Menurut Muhammad Abduh, orang Arab sepakat bahwa kata 'ālamin tidak digunakan untuk merunjuk kepada segala sesutu yang ada, seperti alam batu dan tanah. Akan tetapi, mereka memakai 'ālamīn untuk merunjuk kepada setiap makhluk Tuhan yang berakal, atau mendekati sifat-sifat berakal, seperti alam manusia, hewan dan tumbuhan.

Kesimpulan dari penjelasan di atas, bahwa manusia diperintahkan oleh Allah untuk menggali dan memperdalam ilmu penngetahuan dan teknologi dengan segala kemampuan yang dimillikinya dengan mengacu kepada sumber aslinya. Sehingga ilmu yang dihasilkan nantinya adalah ilmu yang bermanfaat. Karena Allah "menampakkan" diri-Nya melalui alam dan ayat-ayat-Nya.

\section{Integrasi Iman, Ilmu dan Amal dalam Menciptakan Kemaslahatan di Dunia}

Dalam pandangan Islam, antara agama, ilmu pengetahuan, dan perbuatan merupakan hubungan yang sangat harmonis yanng terintegrasi ke dalam suatu sistem yang sangat kuat yaitu Dìn al-Isläm. Didalamnya terkandung tiga unsur pokok, yaitu: akidah, syari'ah dan akhlak. Dengan kata lain iman, ilmu dan amal salih. Sesuai dengan firman Allah:

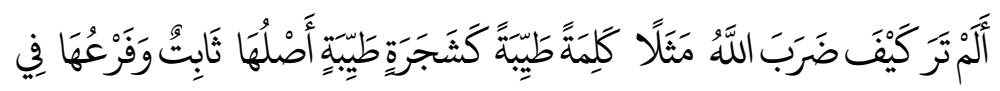

27Mehdi Golshani, Filsafat Sains Menurut al-Qur'an, h. 68.

Walisongo, Volume 23, Nomor 2, November 2015 


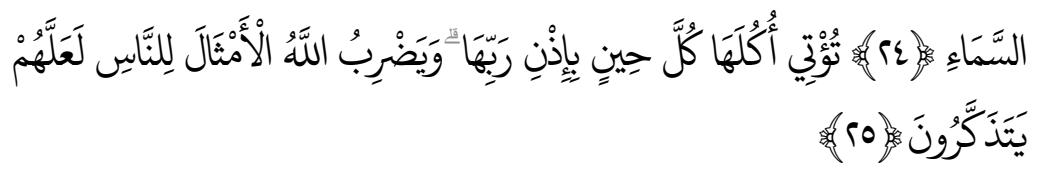

"Tidakkah kamu perhatikan bagaimana Allah telah membuat perumpamaan kalimat yang baik seperti pohon yang baik, akarnya teguh dan cabangnya (menjulang) ke langit, pohon itu memberikan buahnya pada setiap musim dengan seizin Tuhannya. Allah membuat perumpamaan-perumpamaan itu untuk manusia supaya mereka selalu ingat."28

Ayat di atas menggambarkan keutuhan antara iman, ilmu dan amal atau aqidah, syari'ah dan akhlak dengan menganalogikan bangunan Dìn al-Isläm bagaikan sebatang pohon yan baik. Dimana akarnya menghujam ke bumi, batangnya menjulang tinggi ke langit, cabangnya atau dahannya rindanng dan buahnya amat lebat. Ini merupakan gambaran bahwa antara iman, ilmu dan amal merupakan satu kesatuan yang utuh tidak dapat dipisahkan antara satu sama lainnya. Iman diidentikkan dengan akar dari sebuah pohon yang menopang tegaknya ajaran Islam. Ilmu bagaikan batang pohon yang mengeluarkan dahan-dahan dan cabang-cabang ilmu pengetahuan. Sedangkan amal ibarat buah dari pohon itu identik dengan teknologi dan seni. Iptek yang dikembangkan di atas nilai-nilai iman dann ilmu akan menghasilkan amal salih, bukan kerusakan alam.

Dari penjelasan di atas, konsep pelakasanaan dari semua itu bisa kita laksanakan, asalkan kita harus menjalakannya sesuai dengan syariat Islam. Karena agama Islam mengandung ajaran untuk menciptakan kedamaian, keselamatan dan kesejahteraan kehidupan umat manusia khususnya, dan semua makhluk Allah pada umumnya. Kondisi ini akan terwujud apabila manusia sebagai hamba Allah dapat menjalankan aturan-Nya tersebut secara benar dan käffah. Selain itu, hanya orang-orang yang memiliki dan mampu mendayagunakan akalnya secara optimal dan memiliki kapasitas intelektual yakni kesanggupan memikirkan fenomena alam dan peristiwa kehidupan. Sehingga nantinya akan mengantarkan mereka menjadikan ulu al-albāb.

Dari kesimpulan itu, pada gilirannya akan menumbuhkan kesadaran yang mendalam akan kebesaran Tuhan. Dengan memikirkan fenomena alam dan peristiwa kehidupan sehingga mampu memahami hukum-hukumnya

${ }^{28}$ QS. Ibrahim [14]: 24-25. 
(Sunnatullāh) itulah yang akan membuat ilmu pengetahuan dan teknologi akan berkembang. Sedangkan ilmu yang dikembangkan oleh ulu al-albāb bukan hanya sekedar ilmu untuk ilmu, tetapi selain ilmu yang bermanfaat bagi kehidupan juga ilmu yang membawa peningkatan iman kepada Allah karena menyadari keagunngan Tuhan. Dengan demikian, ulu al-albāb adalah manusia yang memilliki kualitas dzikir dan pikir yang tinggi. Firman Allah:

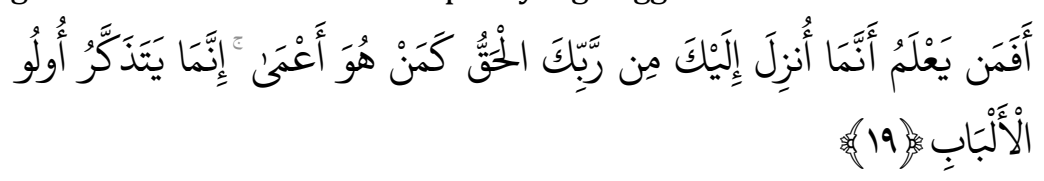

"Adakah orang yang mengetahui bahwasanya apa yang diturunkan kepadamu dari Tuhanmu itu benar sama dengan orang yang buta? Hanyalah orang-orang yang berakal saja yang dapat mengambil pelajaran." 29

Namun, jika kita melihat fenomena bencana asap yang terjadi saat ini, sangatlah memprihatinkan. Penebangan pohon secara liar serta pembakaran hutan yang tidak terkontrol, menyebabkan banyaknya anak-anak yang menderita ISPA bahkan menyebabkan kematian. Ekosistem di hutan rusak menyebabkan banyak hewan yang sudah tidak memiliki tempat tinggal bahkan juga banyak yang mengalami kematian. Hal ini sangatlah disayangkan, karena Allah memerintahkan manusia untuk menggali potensi alam dengan ilmu pengetahuan dan potensi yang dimilikinya, namun tidak menyebabkan penderitaan bagi yang lainnya. Karena ajaran Islam mempunyai karakteristik antara lain:

\section{Sesuai dengan Fitrah Manusia}

Pengertian kesesuaian ajaran Islam dengan fitrah manusia tesebut adalah: a) agama Islam mengandung petunjuk yang sesuai dengan sifat dasar manusia, baik dari aspek keyakinan, perasaan, maupun pemikiran; b) sesuai dengan kebutuhan hidup manusia; c) Memberikan manfaat tanpa menimbulkan komplikasi; dan d) menempatkan manusia dalam posisi yang benar. Kondisi ini ditegaskan Allah dalam al-Qur'an:

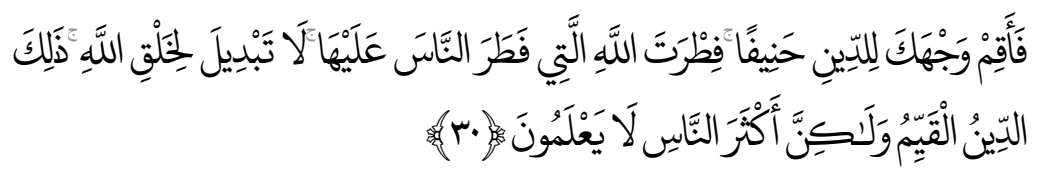

${ }^{29}$ QS. al-Ra'd [13]: 19.

Walisongo, Volume 23, Nomor 2, November 2015 
"Maka hadapkanlah wajahmu dengan lurus kepada agama Allah; (tetaplah atas) fitrah Allah yang telah menciptakan manusia menurut fitrah itu. Tidak ada peubahan pada fitrah Allah. (Itulah) agama yang lurus; tetapi kebanyakan manusia tidak mengetahui." 30

\section{Kebenarannya Mutlak}

Kebenaran mutlak ajaran Islam itu dapat dipahami, karena ajaran Islam berasal dari Allah yang Mahabenar, dan dapat pula dipahami melalui buktibukti materiil, serta bukti riilnya. Karena Allah mengingatkan agar manusia tidak meragukan kebenarannya, sebagaimana difirmankan:

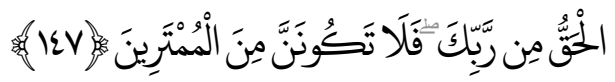

"Kebenaran itu adalah dari Tuhanmu, sebab itu jangan sekali-kali kamu termasuk orang-orang yang ragu." 31

\section{Mengajarkan Keseimbangan dalam Berbagai Aspek Kehidupan}

Sekalipun menurut ajaran Islam, manusia diciptakan hanya untuk beribadah kepada Allah, tetapi nilai ibadah tersebut terdapat pada selruh aspek kehidupan, dan manusia harus memperhatikan berbagai aspek kepentingan dalam hidupnya tersebut. Sebagaimana firman Allah:

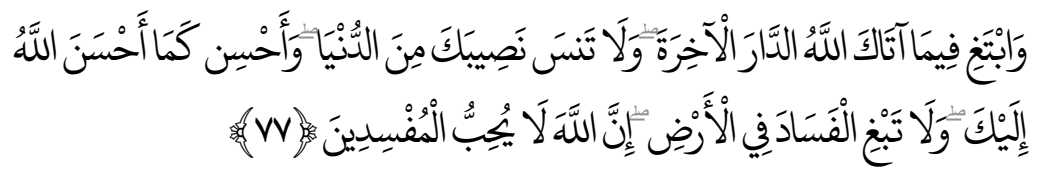

"Dan carilah pada apa yang telah dianugerahkan Allah kepadamu (kebahagiaan) negeri akhirat, dan janganlah kamu melupakan bagianmu dari (kenikmatan) duniawi dan berbuat baiklah (kepada orang lain) sebagaimana Allah telah berbuat baik, kepadamu, dan janganlah kamu berbuat kerusakan di (muka) bumi. Sesungguhnya Allah tidak menyukai orang-orang yang berbuat kerusakan."32

\section{Berlaku secara Universal}

Ajaran Islam berlaku untuk seluruh umat manusia sejak diturunkannya ajaran Islam tersebut sampai akhir masa. Penegasan ini dinyatakan:

\footnotetext{
${ }^{30}$ QS. al-Rum [30]: 30

${ }^{31} \mathrm{QS}$. al-Baqarah [2]: 147.

${ }^{32}$ QS. al-Qashash [28]: 77.
} 


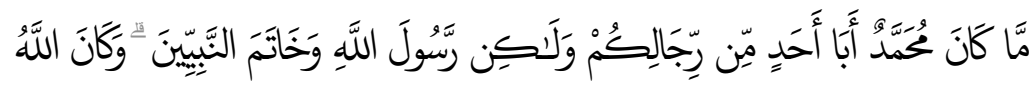

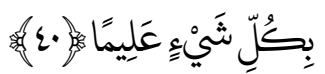

"Muhammad itu sekali-kali bukanlah bapak dari seorang laki-laki di antara kamu, tetapi dia adalah Rasulullah dan penutup nabi-nabi. Dan adalah Allah Maha Mengetahui segala sesuatu." 33

\section{Bersifat Raḥmatan li '-'Āàlamīn}

Ajaran Islam diturunkan untuk mewujudkan rahmat, kasih sayang Allah terhadap makhluk-Nya, seperti ketenangan, kedamaian dan kebahagiaan hidup serta kemaslahatan bagi semua makhluk-Nya. Hal ini dinyatakan oleh Allah:

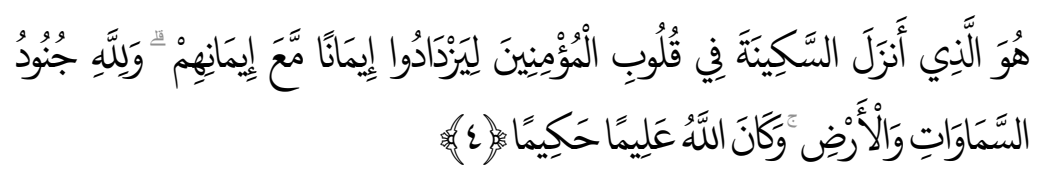

"Dialah yang telah menurunkan ketenangan ke dalam hati orang-orang mukmin supaya keimanan mereka bertambah di samping keimanan mereka (yang telah ada). Dan kepunyaan Allah-lah tentara langit dan bumi dan adalah Allah Maha Mengetahui lagi Maha Bijaksana.." 34

Fungsi agama Islam sebagai rahmat Allah tidak bergantung pada penerimaan atau penilaian Manusia. Subtansi rahmat teletak pada fungsi ajaran tersebut, dan fungsi itu baru akan dirasakan, baik oleh manusia sendiri maupun oleh makhluk yang lain, apabila manusia sebagai pengembangan amanah Allah telah mentaati ajaran Islam tersebut. Karunia akal bagi umat manusia telah cukup untuk membuat pertimbangan, apakah ia akan menerima dan mentaati petunjuk Allah tersebut atau akan mengingkarinya.

\section{Islam Mengatur Pemanfaatan Alam secara Baik dan Proporsional}

Allah berfirman:

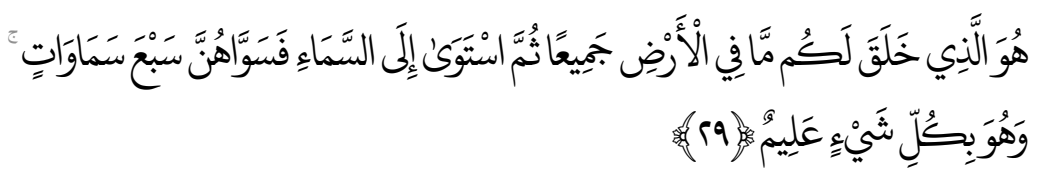

${ }^{33}$ QS. al-Ahzab [33]: 40.

${ }^{34} \mathrm{QS}$. al-Fath [48]:4.

Walisongo, Volume 23, Nomor 2, November 2015 
"Dialah Allah, yang menjadikan segala yang ada di bumi untuk kamu dan Dia berkehendak (menciptakan) langit, lalu dijadikan-Nya tujuh langit. Dia Maha Mengetahui segala sesuatu.." 35

Walaupun Allah memberikan hak kepada manusia untuk menggali dan memanfaatkan segala yang ada di muka bumi ini, namun Allah juga mengingatkan kepada manusia untuk menjaga kelestarian alam lingkungan serta tidak melakukan kerusakan di atas muka bumi ini. Sesuai dengan firman Allah:

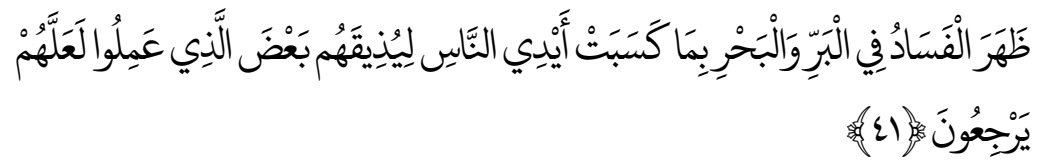

"Telah nampak kerusakan di darat dan di laut disebabkan karena perbuatan tangan manusia, supaya Allah merasakan kepada mereka sebahagian dari (akibat) perbuatan mereka, agar mereka kembali (ke jalan yang benar)." 36

Demikianlah Allah telah menjelaskan dalam al-Qur'an, begitu pentingnya keseimbangan antara iman, ilmu dan amal sehingga apa yang dihasilkan selalu memberikan manfaat bagi orang lain.

\section{E. Kesimpulan}

Begitu sentral dan tingginya derajat manusia sehingga fungsi dari penciptaannya di dunia ini sebagai khalīfah fi'l-ard, dengan memiliki iman yang kuat serta dibekali dengan ilmu pengetahuan yang tinggi, sehingga derajatnya diangkat oleh Allah. Untuk itu, manusia mempunyai amanat yang besar untuk menciptakan dan menghasilkan segala bentuk yang ada dimuka bumi ini, dengan modal potensi yang diberikan Allah kepada manusia. Untuk mewujudkan semua itu, diperlukan bukan hanya manusia sebagai penghuni dimuka bumi saja. Namun, lebih jelasnya manusia yang mampu mengaplikasikan segala potensi itu demi terwujudnya rạ̣matan li 'l-ālamīn. Semua itu, bisa dilakukan oleh manusia-manusia yang berkualitas baik dari segi jasmani dan ruhani atau sebagai manusia yang mempunyai predikat ulu al-albāb. [w]

${ }^{35}$ QS. al-Baqarah [2]: 29.

${ }^{36}$ QS. al-Rum [30]: 41: 


\section{BIBLIOGRAPHY}

Abu Daud Sulaiman, Sunan Abū Dawūd (Collection of Hadits Abu Dawud), Beirut: Dar al-Ihya' al-Turath al-Araby, n.d.

Ali bin Muhammad al-Jarnuji, Kitāb al-Ta'rīfāt (Book of Definitions), Beirut: Dār al-Kutub al-Imiyyah, 1988.

Ali Khallil Abu al-'Ainain, Filsafat al-Tabiyyah al-Islāmiyyah fi 'l-Qur'ān al-Karīm (Pholosphy of Islamic Eduaction According to al-Qur'an al-Karim), n.p, Dar al-Fikr al-'Araby, 1980.

Badri Yatim, Sejarah Peradaban Islam (History of Islamic Civilization), Jakarta: Raja Grafindo Persada, 1997.

Baedhowi, Antropologi al-Qur'an (Anthropology of al-Qur'an), Yogyakarta: LKIS, 2009.

Baiquni, A., Islam dan Ilmu Pengetahuan (Islam and Science), Bandung: Pustaka, 1983.

Briffault, Robert, The Making of Humanity, Montana: Kessinger Publishing, LLC, 2010.

Fazlur Rahman, Tema Pokok al-Qur'an (Main Themes of al-Qur'an), translated by Anas Mahyuddin, Bandung: Pustaka, 1996.

Hasan Basri Jumin, Sains dan Teknologi dalam Islam: Tinjauan Genetis dan Ekologis (Science and Technology in Islam: Genetic and Ecologic Perspective), Jakarta: Raja Grafindo Persada, 2012.

Hasymi, A., Sejarah Kebudayaan Islam (History of Islamic Culture), Jakarta: Bulan Bintang, 1979.

Imam Syafi'e, Konsep Ilmu Pengetahuan dalam al-Qur'an (Concept of Science in al-Qur'an), Yogyakarta: UII Press, 2000.

Jamil Shaliba, al-Mu'jam al-Falsafi (Encyclopedia of Philosophy), Beirut: Dar alKitab al-Lubnani, 1973.

Jhon M. Echols \& Hasan Shadily, Kamus Inggris-Indonesia (English-Indonesian Dictionary), Jakarta: Gramedia, 1996.

Walisongo, Volume 23, Nomor 2, November 2015 
M. Dawam Rahardjo, Ensiklopedi al-Qur'an: Tafsir Sosial Berdasarkan KonsepKonsep Kunci (Encyclopedia of al-Qur'an: Social Interpretation According to Main Concepts), Jakarta: Paramadina, 2002.

Mahdi Gholshani, Filsafat Sains Menurut al-Qur'an (Philosophy of Sciences According to al-Qur'an), translated by Agus Effendi, Bandung: Mizan, 1998.

Mohammad Iqbal, Membangun Kembali Pikiran Agama dalam Islam (The Reconstruction of Religious Thought in Islam), translated by Ali Audah et.al., Jakarta: Tinta Emas, 1966.

Mujamil Qomar, Epistemologi Pendidikan Islam dari Metode Rasional Hingga Metode Kritik (Epistemology of Islamic Education from Rational to Critical Method), Jakarta: Erlangga, 2007.

al-Nahlawi, Aburrahman, Ușūl al-Tarbiyah al-Islāmiyyah wa Asālibuhā fi 'l-Bayti wa al-Madrasati wa al-Mujtamā', (The Basics and Methods of Islamic Education in Family, School, and Community), Dar al-Fikr al-Mu'ashir, Bairut-Libanon, 1403 H/ 1983 AD.

Nurcholis Madjid, Islam: Doktrin dan Peradaban - Sebuah Telaah Kritis tentang Masalah Keimanan, Kemanusiaan dan Kemoderenan (Islam: Doctrine and Civilization: a Critical Discussion about Belief, Humanity and Modernity), Jakarta: Paramadina, 2000.

Sirajuddin Zar, Konsep Penciptaan Alam dalam Pemikiran Islam, Sains, dan alQur'an (Concept of Creation of the Universe in the Thought of Islam, Science and al-Qur'an), Jakarta: Raja Grafindo Persada, 1994.

al-Tirmidhi, al-Jāmi' al-Șaḥịh Sunan al-Tirmidhi, (Encyclopedia of Hadith Sahih al-Tirmidhi), Cairo: Mustafá Babi al-Halabi,1962.

Tim Penyusun, Pengembangan Kepribadian Pendidikan Agama Islam pada Perguruan Tinggi (Personality Development of Islamic Studies in Higher Education), Jakarta: Departemen Agama Direktorat Jenderal Pendidikan Islasm Direktorat Pendidikan Tinggi Islam, 2009.

Toto Suharto, Filsafat Pendidikan Islam (Philosophy of Islamic Education), Yogyakarta: Ar-Ruzz, 2006. 